\title{
THE EFFECT OF MELATONIN ON LIPID PEROXIDE OXIDATION, OXIDATIVE MODIFICATION OF PROTEINS AND MITOCHONDRIA SWELLING IN THE SKELETAL MUSCLE TISSUE OF RATS UNDER ALLOXAN DIABETES
}

\author{
I. V. GERUSH, V. V. BEVZO, Ye. O. FERENCHUK \\ HSEI of Ukraine "Bukovinian State Medical University”, Chernivtsi, Ukraine; \\ e-mail: yelena_f@ukr.net
}

The aim of the investigation was to study the effect of melatonin on of peroxide lipid oxidation, the oxidative modification of proteins and the mitochondria swelling in skeletal muscle tissue of rats under alloxan diabetes. The intensification of free radical processes in the mitochondria skeletal of muscle tissue of the diabetic rats was accompanied by an increase in the content of thiobarbiturate-active products and in the oxidation process of proteins mitochondria. It was manifested by the decrease in the content of free SHgroups and the accumulation of carbonyl derivatives. The light scattering of the suspension of mitochondria decreases that evidences for their swelling. So, the mitochondria swelling was found to be associated with the increase of thiobarbiturate-active products and the decreased content of free SH-groups in the mitochondrial fraction of the muscle tissue of diabetic rats. Melatonin has a corrective effect on the processes of free radical oxidation of lipids and proteins of mitochondrial fractions and on the intensity of swelling of mitochondria.

Keywords: alloxan diabetes, lipid peroxide oxidation, mitochondria swelling, melatonin, skeletal muscle tissue of rats.

A progressive increase in the number of diabetes patients has become one of the global health problems of the $21^{\text {st }}$ century. In 2015, nearly 415 million people were diagnosed to suffer from diabetes, that is, equal to $8.8 \%$ of population aged 20-79. According to the expert value, if these trends continue, the number of patients will grow to 642 million people by 2040 [1, 2].

It is an endocrine-metabolic disease manifested by the state of chronic hyperglycemia, a violation of all types of metabolism and multiple organ lesions. The pathological increase in glucose concentration in the blood may be due to insufficient synthesis and release of insulin by the $\beta$-cells of the Langenhars islet and with changes in the level of hormonal interaction in insulin-sensitive tissues (liver, muscle and adipose tissue). The above complications lead to an imbalance in the intracellular metabolic level of the target tissues of the hormone, in particular the utilization of glucose, glycolysis and glycogenesis [3-5].

Skeletal muscles are the preferred place for insulin absorption of glucose uptake in the post-ab- sorption period, so the diabetic complications that arise in a hyperglycemic state often lead to loss of skeletal muscle activity and are called diabetic myopathy $[6,7]$. However, the mechanism of development of metabolic complications in diabetes is not understood. Some authors attribute the cause of diabetic myopathy to mitochondrial dysfunction $[8,9]$.

Metabolic disorders are known to be observed in hyperglycemic conditions leading to hypoxia, oxidative stress and changes in the energy system of the organism. Increased levels of glucose in the blood and tissues cause a constant generation of free radicals. They damage the lipid and protein components of cells and contribute to the formation and accumulation of lipoperoxide compounds, which enhance the processes of destabilization of cell membranes [10].

The mitochondrial oxidative phosphorylation system has an important place in the process of energy production. One of the integral markers of mitochondrial dysfunction is their ability to swell as a result of nonspecific insight into the mitochon-

(C) 2018 Gerush I. V. et al. This is an open-access article distributed under the terms of the Creative Commons Attribution License, which permits unrestricted use, distribution, and reproduction in any medium, provided the original author and source are credited. 
drial membrane. It leads to excessive flow of water in mitochondria, their swelling, and dissociation of oxidation and phosphorylation processes, causing conditions for energy deficiency [11].

Melatonin has recently attracted the attention of physicians and scientists as a neuroendocrine hormone with antioxidant properties. Melatonin is evidenced to stimulate a number of antioxidative enzymes and increase the efficiency of the electron transport chain and, as a result, to reduce electron leakage and generation of free radicals. There is the evidence that the hormone stabilizes microsomal membranes helping them resist oxidative damage [12]. As a chronobiological and cytoprotective agent, melatonin has a special place in the prophylaxis and treatment of metabolic syndrome [13]. It has been shown [14] that melatonin is not only digested with mitochondria, but these organelles, unlike many other functions, are also likely to produce melatonin. It has been established [13] that the level of melatonin decreases in diseases associated with insulin resistance and diseases known as metabolic syndrome.

So the aim of our work is to study the effect of melatonin on the intensity of peroxide lipid oxidation, oxidative modification of proteins, and the intensity of swelling of mitochondria in the muscle tissue of skeletal muscles of rats with diabetes mellitus.

\section{Materials and Methods}

The experiment was conducted on 60 male albino rats with the body weight $0.16-0.18 \mathrm{~kg}$. All manipulations with animals were carried out according to European Convention for the Protection of Vertebrate Animals Used for Experimental and Other Scientific Purposes (Strasbourg, 1986). Rats were kept under the standard vivarium conditions at constant temperature and basic allowance. Animals were narcotized with chloroform and then sacrificed using cervical dislocation. All procedures were executed separately from other rats.

Experimental diabetes was simulated by $5 \%$ alloxan monohydrate solution in the dose of $150 \mathrm{mg} /$ $\mathrm{kg}$. After diabetes was confirmed (fasting blood glucose level was increased in to $12,16 \mathrm{mmol} / \mathrm{l}$ using glucometer "OneTouch"), rats were divided into groups: 1) control rats (C); 2) alloxan diabetic rats (D); 3) animals with overt diabetes, were introduced melatonin intragastrically in the dose of $10 \mathrm{mg} / \mathrm{kg}$ at 8 a.m. during 7 and 14 days $(D+M)$. The skeletal muscle sample of each animal was removed, cleaned, dried and processed for biochemical measurements.
Mitochondria were isolated by differential centrifugation in the isolation buffer [15]. The rats' hip muscle was washed with a cooled $0.9 \%$ solution of $\mathrm{KCl}\left(2-4{ }^{\circ} \mathrm{C}\right)$, chopped and homogenized in 10 times the volume of buffer $\mathrm{pH}$ 7.4: sucrose $-250 \mathrm{mmol} / \mathrm{l}$, tris- $\mathrm{HCl}-25 \mathrm{mmol} / \mathrm{l}$. The homogenate was centrifuged at $700 \mathrm{~g}$ for $10 \mathrm{~min}\left(4^{\circ} \mathrm{C}\right)$, and the supernatant - at $11000 \mathrm{~g}$ for $20 \mathrm{~min}\left(4^{\circ} \mathrm{C}\right)$. The precipitate was resuspended in $5 \mathrm{ml}$ of the same buffer (without EDTA) and centrifuged again under the same conditions. The resulting precipitate (mitochondrial fraction) was resuspended in buffer ( $\mathrm{mmol} / \mathrm{l})$ : sucrose -250 , tris- $\mathrm{HCl}-25$ and used immediately in experiments. The purity of the mitochondrial fraction was controlled by the ratio of DNA/protein [16]. The spectrophotometric method (Agilent Cary 60) of assigning nucleic acids of extraction from the biological material with hot chloric acid to the onset of the discharge of the clay antagonists in the ultraviolet region of the spectrum at 270 to $290 \mathrm{~nm}$ [17]. The protein level was determined by Lowry's method [18]. The kinetics of mitochondria swelling was measured by the decrease in absorbancy $520 \mathrm{~nm}$ for 60 min using spectrophotometer Agilent Cary 60 [19].

A relative rate of swelling of mitochondria in the incubation solution was calculated by changing the value of $\mathrm{E}_{520}$. The native mitochondria were placed in an incubation buffer of isotonic composition (mmol/l): sucrose $-150, \mathrm{KCl}-50, \mathrm{KH}_{2} \mathrm{PO}_{4}-$ 2 , succinate -1 , tris- $\mathrm{HCl}-5, \mathrm{pH} 7.4$ (final volume $3 \mathrm{ml}$ ) and recorded a decrease in the optical density of the mitochondrial suspension at a wavelength of $520 \mathrm{~nm}$ for $60 \mathrm{~min}$ of swelling in the presence of an inductor of $\mathrm{Ca}^{2+}(50 \mu \mathrm{mol} / \mathrm{l})$. The concentration of protein in the incubation medium was $0.4 \mathrm{mg} /$ $\mathrm{ml}$. The change in the level of swelling of the organelles was determined as the difference between the rate of swelling of mitochondria at 5, 10, 20, 30, 40, 60 min relative to the initial value. As control, a mitochondria suspension was used in an incubatory environment in the absence of an inductor with subsequent recording of the optical density for $60 \mathrm{~min}$. By changing the value of $E_{520}$, the relative rate of swelling of mitochondria in the medium of incubation was calculated. Lipid peroxidation (LPO) was estimated by measuring levels of thiobarbituric acid active products [20, 21].

The level of carbonylation of mitochondrial proteins was estimated by the number of derivatives of 2,4-dinitrophenylhydrazone and expressed 
in nmol of carbonyl derivatives per $1 \mathrm{mg}$ of protein. The content of carbonyl derivatives was calculated by the molar extinction coefficient of $21000 \mathrm{M}^{-1} \mathrm{~cm}^{-1}$ [22]. The content of protein SH-groups was determined by the method [23] based on the interaction of Elmann reagent (5,5'-dithio-bis(2-nitrobenzoic acid) with $\mathrm{SH}$-groups. The content of free $\mathrm{SH}$-groups was calculated using a molar extinction coefficient of $11400 \mathrm{M}^{-1} \mathrm{~cm}^{-1}$ and expressed in $\mathrm{nmol} / \mathrm{mg}$ protein.

The type of distribution was estimated using Shapiro-Wilk test. Estimation of the differences between the samples, for normal distribution, for glucose level in the blood and body weight of animals (Table 1) was conducted using parametric Student's $t$-test. Combined sets, light scattering of mitochondria (Fig. 4, 5) was estimation using nonparametric T-Wilcoxon criterion and for independent aggregates (Fig. 1-3, 6) - the Mann-Whitney U-criterion. The level of significance was $P<0.05$. All results in figures are represented as median minimum-maximum values (Me[min-max]), the results in the Table are represented as mean \pm standard error of the mean ( $\mathrm{M} \pm \mathrm{SEM})$ [24].

\section{Results and Discussion}

In the experimental groups was registered an increase of glucose level in the blood and a decrease of the weight of animals (Table 1). In the development of experimental alloxan diabetes the level of glucose in the blood of rats was significantly increased. Thus the level of glucose on the $14^{\text {th }}$ day of experiment was $12.31 \pm 0.33 \mathrm{mmol} / \mathrm{l}$, in the control group of animals $-6.21 \pm 0.24 \mathrm{mmol} / \mathrm{l}$. The introduction of melatonin caused a significant decrease $(10.12 \pm 0.28 \mathrm{mmol} / \mathrm{l})$. Moreover, in animals with alloxan diabetes mellitus, the weight of the body was decreased $(0.12 \pm 0.01 \mathrm{~kg})$, whereas the weight of the control was $0.17 \pm 0.01 \mathrm{~kg}$. The introduction of melatonin prevented a body weight decrease $(0.15 \pm 0.01 \mathrm{~kg})$. Some studies [25-27] have revealed that melatonin affects the insulin secretion via MT1 and MT2 receptors. And the introduction of mela- tonin to diabetic rats reduces the level of glucose and increases fatty acids by modulating insulin release [28]. There is also evidence [29] that melatonin increases the phosphorylation level of insulin receptor substrate-1 (IRS-1) and the activity of phosphoinositide 3-kinase (PI-3-kinase). So melatonin stimulates glucose transport to skeletal muscle cells via IRS-1/ PI-3-kinase pathway, which implies its role in glucose homeostasis by diabetes mellitus. We investigate an effect of melatonin on swelling of mitochondria to confirm its antihyperglycemic properties.

In the mitochondrial fraction of skeletal muscle of diabetic rats 26 and $49 \%$ increase of the content of thiobarbiturate-active products on the 7 and 14 days of the experiment respectively was observed as compared to the control group of animals (Fig. 1).

This result suggests that the intensity of free radical processes increases in case of diabetes mellitus. The study showed increase of the content of carbonyl derivatives and oxidative modifications of SH-groups during the whole experimental period.

Thus, the level of oxidative modification of mitochondrial proteins of the muscle tissue, insoluble in $0.05 \mathrm{M}$ Na-phosphate buffer, on the $14^{\text {th }}$ day of the study was by $34 \%$ higher than that of the control values (Fig. 2). At the same time the oxidation rate of SH-groups increased by 38\% in accordance with the control, and an insignificant increase in the accumulation of carbonyl derivatives of amino acids was observed (Fig. 3).

The changes found in the oxidation of protein molecules are indicative of the disturbance of the prooxidant-antioxidant balance. Confirmation of this fact is the disorder of the barrier function of the mitochondrial membrane in muscle tissue in case of diabetes mellitus. Incubation of isolated mitochondria in the control group for $60 \mathrm{~min}$ has been shown to lead to decrease in light scattering of the suspension (Fig. 4), with a relative swelling rate $2.67 \pm 0.14 \mathrm{unit} / \mathrm{min} / \mathrm{mg}$ protein (Fig. 6).

A gradual decrease in light scattering of the suspension to $0.59 \mathrm{unit} / \mathrm{min} / \mathrm{mg}$ of protein after in-

Ta ble 1. Comparison of glucose levels in the blood and change in weight of rats with diabetic and after melatonin introduction

\begin{tabular}{l|c|c|r|r|r|r}
\hline & C, 7 day & D, 7 day & D + M, 7 day & C, 14 day & D, 14 day & D + M, 14 day \\
\hline Glucose mmol/l & $6.21 \pm 0.24$ & $12.16 \pm 0.36^{\mathrm{a}}$ & $10.22 \pm 0.25^{\mathrm{a}, \mathrm{b}}$ & $6.24 \pm 0.29$ & $12.31 \pm 0.33^{\mathrm{a}}$ & $10.12 \pm 0.28^{\mathrm{a}, \mathrm{b}}$ \\
Weight, kg & $0.17 \pm 0.01$ & $0.15 \pm 0.01^{\mathrm{a}}$ & $0.16 \pm 0.01^{\mathrm{a}, \mathrm{b}}$ & $0.17 \pm 0.01$ & $0.12 \pm 0.01^{\mathrm{a}}$ & $0.15 \pm 0.01^{\mathrm{a}, \mathrm{b}}$ \\
\hline
\end{tabular}

$\mathrm{C}$ - control rats; D - diabetic rats; D + M - animals with diabetes, were introduced melatonin. ${ }^{\text {aSignificant differences }}$ compared to the control; bsignificant differences compared to diabetic animals ( $\mathrm{M} \pm \mathrm{SEM}, n=10, P<0.05)$. 


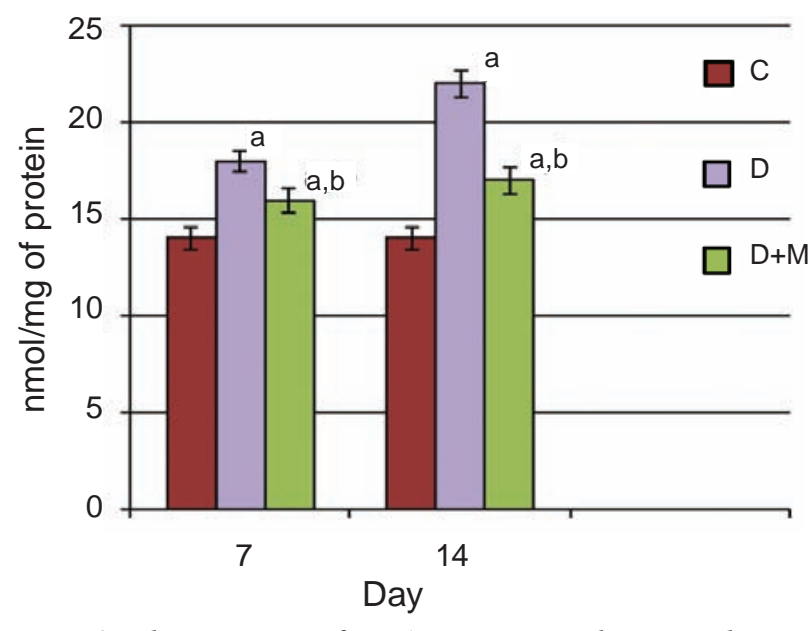

Fig. 1. The content of TBA-active products in the mitochondrial fraction of muscles of diabetic rats after melatonin introduction. $C$ - control, $D$-diabetic rats, $D+M$ - animals with diabetes, were introduced melatonin; $a$ - significant differences compared to the control; $b$ - significant differences compared to diabetic animals. The results are represented as Me[min-max], $n=10, P<0.05$

cubation for 60 min was observed in the group of animals with alloxan diabetes on the $7^{\text {th }}$ day of the experiment. At the same time, the value of a relative rate of mitochondrial swelling was $3.50 \mathrm{unit} / \mathrm{min} /$ $\mathrm{mg}$ of protein that is by $24 \%$ higher than that of the control values.

On the $14^{\text {th }}$ day of the experiment a significant decrease in the light scattering of the mitochondrial suspension was recorded, it was 0.34 unit/mg of protein (Fig. 5). A relative rate of swelling of mitochondria of the skeletal muscles increased to 3.87 unit/ $\mathrm{min} / \mathrm{mg}$ of protein that is 1.45 times more than in the control.

The study of the effect of 14-day introduction of melatonin on the intensity of peroxide lipid oxidation and oxidative modification of mitochondria of the muscle tissue of animals with hyperglycemia showed that melatonin induced decrease in the protein carbonylation and increased the number of free sulfhydryl groups of proteins to the level of control values (Fig. 1-3).

A positive effect of melatonin on free radical lipid and protein oxidation processes can be explained by the fact that it is an antioxidant, being implicated in increasing the concentration of certain antioxidant enzymes, such as catalase, glutathione peroxidase and superoxide dismutase. Therefore, melatonin shows benefits for inhibiting oxidation to oxygen-based free radicals and hydroxyl radicals. In the group of diabetic animals the melatonin introduced decrease in the swelling rate of mitochondria of the skeletal muscle was noticed already on the $7^{\text {th }}$ day of the experiment.

A positive effect of melatonin on the rate of swelling of mitochondria against the background of hyperglycemia was observed on the $14^{\text {th }}$ day of the experiment. At the same time, a relative swelling rate was $3.0 \pm 0.15 \mathrm{unit} / \mathrm{min} / \mathrm{mg}$ of protein and did not differ significantly from the control values (Fig. 6).

A correction effect of melatonin on the rate of swelling of mitochondria in the skeletal muscles of rats with diabetes mellitus is likely to occur due to its antioxidant properties.

Melatonin is known to inhibit the formation of free radicals, and so stabilizes biological membranes, reduces the rate of mitochondria swelling and is an effective protector of mitochondrial bioenergetic function. In recent years, some experimental studies have been showing that melatonin protects the mitochondria membrane in different ways [30, 31]. First of all, it reduces NO due to lowregulating induction and inhibition of neuronal oxide signals (iNOS, nNOS), thus preventing excess levels of peroxynitrite. Secondly, melatonin improves the

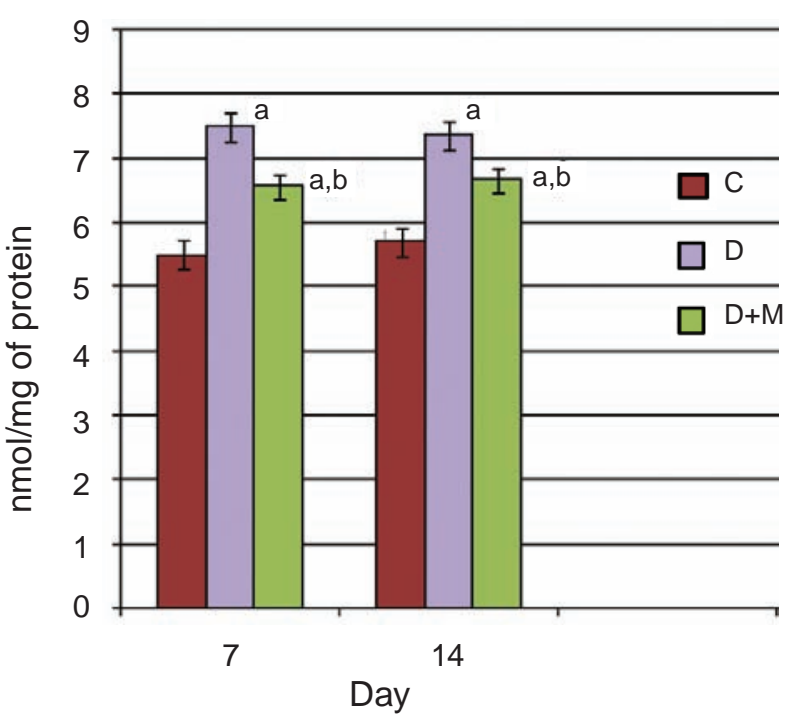

Fig. 2 The level of carbonyl derivatives of mitochondrial proteins of the muscle tissue of diabetic rats with melatonin introduction. $C$ - control, $D-$ diabetic rats, $D+M$ - animals with diabetes, were introduced melatonin; $a$ - significant differences compared to the control; $b$ - significant differences compared to diabetic animals. The results are represented as Me[min-max], $n=10, P<0.05$ 


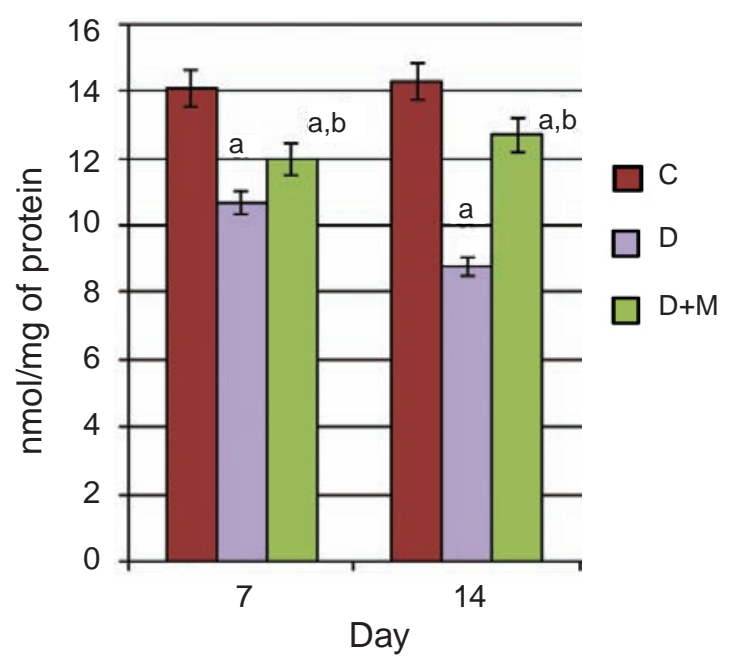

Fig. 3 The level of SH-groups of mitochondrial proteins of the muscle tissue of diabetic rats with melatonin introduction. $(C-$ control, $D$-diabetic rats, $D+M$ - animals with diabetes, were introduced melatonin; $a$ - significant differences compared to the control; $b$ - significant differences compared to diabetic animals. The results are represented as Me [min-max], $n=10, P<0.05$ )

anti-oxidative protection of the intracerebral tissue by increasing glutathione and inducing glutathione peroxidase and superoxide dismutase (Mn-SOD) in the matrix and $\mathrm{Cu}, \mathrm{Zn}-\mathrm{SOD}$ in the intermembrane space. Additional action refers to inhibition of the peroxidation of the cardiolipin. Cardiolipin is an important component of the inner mitochondrial membrane, where it constitutes about $20 \%$ of the total lipid composition. It plays a key role in stability, dynamics and control of bioenergetic processes of mitochondrial membrane. These positive changes

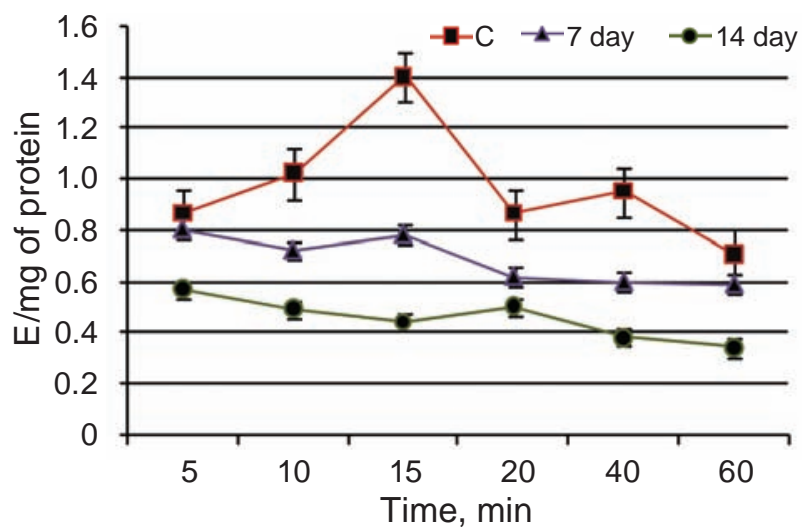

Fig. 4. Light scattering of mitochondria of the muscle tissue of rats under alloxan diabetes. The results are represented as Me[min-max], $n=10, P<0.05$

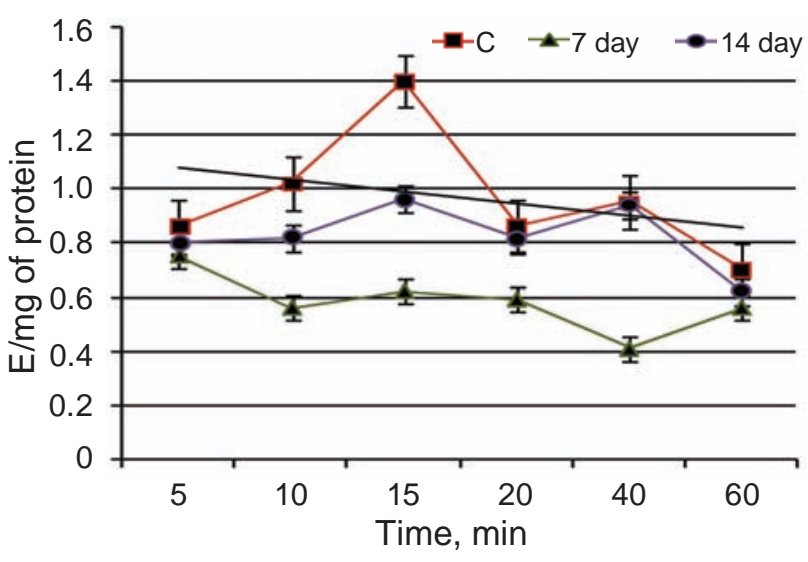

Fig. 5. Light scattering of mitochondria of the muscle tissue of rats under alloxan diabetes and melatonin introduction. The results are represented as Me [min-max], $n=10, P<0.05$

are a necessary condition for increasing the energy potential of muscle cells to implement an adaptive body reaction in case of diabetes mellitus [32].

Thus, the intensification of free radical processes in the mitochondrial fraction of muscle tissue of diabetic rats is accompanied by an increase in the content of thiobarbiturate-active products and in the oxidation process of mitochondrial proteins. It is manifested by the decrease in the content of free

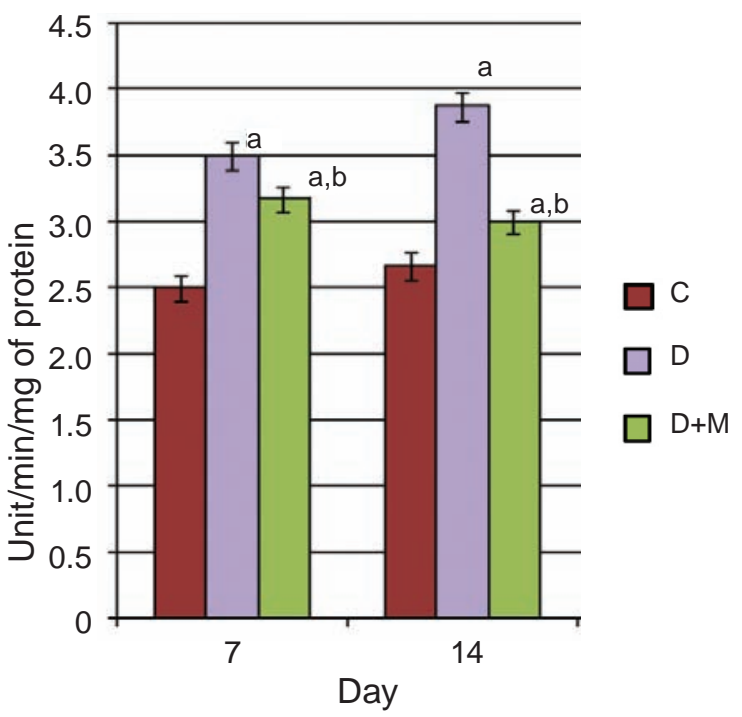

Fig. 6 Relative swelling rate of mitochondria of the muscle tissue of rats under alloxan diabetes. $C$ - control, $D$ - diabetic rats, $D+M$ - animals with diabetes, were introduced melatonin; $a$ - significant differences compared to the control; $b$ - significant differences compared to diabetic animals. The results are represented as Me [min-max], $n=10$, $P<0.05$ 
SH-groups and the accumulation of carbonyl derivatives. In addition, the light scattering of the suspension of mitochondria decreases, which is indicative of their swelling and therefore possible reduction of energy production in insulin-dependent muscle tissue of rats.

Such change can be considered as a compensatory reaction of the organism to oxidative stress caused by high glucose level. The introduction of melatonin during 7 days produces a positive effect on free radical oxidation processes of lipids and proteins of the mitochondrial fraction and on the intensity of mitochondria swelling against the background of hyperglycemia.

The work has defined an increase in the content of thiobarbiturate-active products in the mitochondrial fraction of muscle tissue of diabetic rats against the background of decreasing the content of free SHgroups and the accumulation of carbonyl derivatives of mitochondrial proteins and as a result, mitochondria swelling.

The result of the work demonstrates a corrective effect of melatonin on the investigated processes of free radical oxidation of lipids and proteins of mitochondrial fraction and on the intensity of mitochondria swelling of rats with alloxan-simulated diabetes mellitus.

\section{ВПЛИВ МЕЛАТОНІНУ НА ПЕРОКСИДНЕ ОКИСЛЕННЯ ЛІПІДІВ, ОКИС ЛЮВАЛЬНУ МОДИФІКАЦІЮ ПРОТЁ̈НІВ ТА НАБУХАННЯ МІТОХОНДРІЙ У СКЕЛЕТНІЙ М'ЯЗОВІЙ ТКАНИНІ ЩУРІВ В УМОВАХ АЛОКСАНОВОГО ДІАБЕТУ}

\author{
I. В. Геруи, В. В. Бевзо, С. О. Ференчук \\ ВДНЗ України «Буковинський державний \\ медичний університет», Чернівці; \\ e-mail: yelena_f@ukr.net
}

Метою роботи було дослідити вплив мелатоніну на інтенсивність пероксидного окислення ліпідів, окислювальну модифікацію протеїнів та набухання мітохондрій у скелетній м'язовій тканині щурів в умовах алоксанового діабету. Діабет у щурів моделювали введенням 5\%-го розчину алоксанмоногідрату (150 мг/кг). Встановлено, що вміст ТБК-активних продуктів у мітохондріальній фракції скелетних м'язів щурів із алоксановим діабетом зростав на фоні зменшення числа вільних SH-груп та накопичення карбонільних похідних протеїнів мітохондрій. Виявлено корегуючий вплив мелатоніну на процеси вільнорадикального окислення ліпідів і протеїнів мітохондрій та на інтенсивність їх набухання.

К л ючов і с лов а: алоксановий діабет, пероксидне окислення ліпідів, набухання мітохондрій, мелатонін, скелетна м'язова тканина щурів.

ВЛИЯНИЕ МЕЛАТОНИНА НА
ПЕРОКСИДНОЕ ОКИСЛЕНИЕ
ЛИПИДОВ, ОКИСЛИТЕЛЬНУЮ
МОДИФИКАЦИЮ ПРОТЕИНОВ
И НАБУХАНИЕ МИТОХОНДРИЙ
В СКЕЛЕТНОЙ МЫШЕЧНОЙ
ТКАНИ КРЫС В УСЛОВИЯХ
АЛЛОКСАНОВОГО ДИАБЕТА

И. В. Геруш, В. В. Бевзо, Е. А. Ференчук

ВГНУ Украины «Буковинский государственный медицинский университет», Черновцы; e-mail: yelena_f@ukr.net

Целью работы было исследовать влияние мелатонина на интенсивность пероксидного окисления липидов, окислительную модификацию протеинов и набухание митохондрий в скелетной мышечной ткани крыс в условиях аллоксанового диабета. Диабет у крыс моделировали введением 5\%-го раствора алоксанмоногидрата (150 мг/кг). Установлено, что содержание ТБК-активных продуктов в митохондриальной фракции скелетной мышечной ткани крыс с аллоксановым диабетом повышалось на фоне уменьшения содержания свободных $\mathrm{SH}-г р у п п ~$ и накопления карбонильных производных протеинов митохондрий. Определено корректирующее влияние введения мелатонина на процессы свободнорадикального окисления липидов и протеинов митохондрий, а также на интенсивность их набухания.

К л ю че вы е с лов а: аллоксановый диабет, пероксидное окисление липидов, набухание митохондрий, мелатонин, скелетная мышечная ткань крыс. 


\section{References}

1. Standards of medical care in diabetes. American Diabetes Association. 2016; 39: 112.

2. Handelsman Y, Bloomgarden ZT, Grunberger G, Umpierrez G, Zimmerman RS, Bailey TS, Blonde L, Bray GA, Cohen AJ, Dagogo-Jack S, Davidson JA, Einhorn D, Ganda OP, Garber AJ, Garvey WT, Henry RR, Hirsch IB, Horton ES, Hurley DL, Jellinger PS, Jovanovič L, Lebovitz HE, LeRoith D, Levy P, McGill JB, Mechanick JI, Mestman JH, Moghissi ES, Orzeck EA, Pessah-Pollack R, Rosenblit PD, Vinik AI, Wyne K, Zangeneh F. American association of clinical endocrinologists and american college of endocrinology - clinical practice guidelines for developing a diabetes mellitus comprehensive care plan - 2015. Endocr Pract. 2015; 21(Suppl 1): 1-87.

3. Kyznietsova MY, Halenova TI, Savchuk OM, Vereschaka VV, Ostapchenko LI. Carbohydrate metabolism in type 1 diabetic rats under the conditions of the kidney bean pods aqueous extract application. Fiziol Zh. 2015; 61(6): 96103. (In Ukrainian).

4. Smith CJ, Ryckman KK. Epigenetic and developmental influences on the risk of obesity, diabetes, and metabolic syndrome. Diabetes Metab Syndr Obes. 2015; 8: 295-302.

5. Gumieniczek A, Hopkała H, Wójtowicz Z, Nieradko M. Differences in antioxidant status in skeletal muscle tissue in experimental diabetes. Clin Chim Acta. 2001; 314(1-2): 39-45.

6. DeFronzo RA, Tripathy D. Skeletal muscle insulin resistance is the primary defect in type 2 diabetes. Diabetes Care. 2009; 32(Suppl 2): S157-S163.

7. D'Souza DM, Al-Sajee D, Hawke TJ. Diabetic myopathy: impact of diabetes mellitus on skeletal muscle progenitor cells. Front Physiol. 2013; 4: 379.

8. Sreekumar R, Nair KS. Skeletal muscle mitochondrial dysfunction \& diabetes. Indian $J$ Med Res. 2007; 125(3): 399-410.

9. Phielix E, Mensink M. Type 2 diabetes mellitus and skeletal muscle metabolic function. Physiol Behav. 2008; 94(2): 252-258.

10. Reiter RJ, Tan DX, Manchester LC, Qi W. Biochemical reactivity of melatonin with reactive oxygen and nitrogen species: a review of the evidence. Cell Biochem Biophys. 2001; 34(2): 237-256.
11. Lyu BN, Lyu MB. The Oxygen-Peroxide Concept of Apoptosis: Increased Argumentation and Further Development. Biol Bull Rev. 2005; 125(6): 567-578.

12. Anisimov VN, Popovich IG, Zabezhinski MA, Anisimov SV, Vesnushkin GM, Vinogradova IA. Melatonin as antioxidant, geroprotector and anticarcinogen. Biochim Biophys Acta. 2006; 1757(5-6): 573-589.

13. Cardinali DP, Vigo DE. Melatonin, mitochondria, and the metabolic syndrome. Cell Mol Life Sci. 2017; 74(21): 3941-3954.

14. Reiter RJ, Rosales-Corral S, Tan DX, Jou MJ, Galano A, Xu B. Melatonin as a mitochondriatargeted antioxidant: one of evolution's best ideas. Cell Mol Life Sci. 2017; 74(21): 3863-3881.

15. Weinbach EC. A procedure for isolating stable mitochondria from rat liver and kidney. Anal Biochem. 1961; 2(4): 335-343.

16. Silaeva SA, Danilova NI, Debov SS. Various properties of ribonucleotide reductase from rat liver mitochondria. Biokhimiia. 1975; 40(4): 711715. (In Russian).

17. Trudolyubova MT. Quantification of RNA and DNA in subcellular cell fractions animals. Modern Methods of Biochemistry. Ed. by. V.N. Orekhovich. M.: Medicine, 1977. 313-316 p. (In Russian).

18. Lowry OH, Rosebrough NJ, Farr AL, Randall RJ. Protein measurement with the Folin phenol reagent. J Biol Chem. 1951; 193(1): 265-275.

19. Stalnaya ID, Garishvili TG. Method of measuring of malonicdialdehyde by thiobarbituric acid. Modern Methods of Biochemistry. Ed. by. V.N. Orekhovich. M.: Medicine, 1977. 66-68 p. (In Russian).

20. Lider VA, Bogdanov NG. Effect of naphthoquinones and tocopherols on the changes in mitochondrial volume. Ukr Biokhim Zhurn. 1985; 57(1): 82-85. (In Russian).

21. Eisenhofer S, Toókos F, Hense BA, Schulz S, Filbir F, Zischka H. A mathematical model of mitochondrial swelling. BMC Res Notes. 2010; 3: 67.

22. Dubinina EE, Burmistrov SO, Khodov DA, Porotov IG. Oxidative modification of human serum proteins. A method of determining it. Vopr Med Khim. 1995; 41(1): 24-26. (In Russian).

23. Murphy ME, Kehrer JP. Oxidation state of tissue thiol groups and content of protein carbonyl groups in chickens with inherited muscular dystrophy. Biochem J. 1989; 260(2): 359-364. 
24. Lapach SN, Chubenko AV, Babich PN. Static methods in biomedical research using Exel. K.: Moion, 2000. 320 p. (In Russian).

25. Bazwinsky-Wutschke I, Bieseke L, Mühlbauer E, Peschke E. Influence of melatonin receptor signalling on parameters involved in blood glucose regulation. J Pineal Res. 2014; 56(1): 8296.

26. Scheer FA, Hilton MF, Mantzoros CS, Shea SA. Adverse metabolic and cardiovascular consequences of circadian misalignment. Proc Natl Acad Sci USA. 2009; 106(11): 4453-4458.

27. Nishida S, Segawa T, Murai I, Nakagawa S. Long-term melatonin administration reduces hyperinsulinemia and improves the altered fatty-acid compositions in type 2 diabetic rats via the restoration of Delta-5 desaturase activity. J Pineal Res. 2002; 32(1): 26-33.

28. Espino J, Pariente JA, Rodríguez AB. Role of melatonin on diabetes-related metabolic disorders. World J Diabetes. 2011; 2(6): 82-91.
29. Ha E, Yim SV, Chung JH, Yoon KS, Kang I, Cho YH, Baik HH. Melatonin stimulates glucose transport via insulin receptor substrate-1/ phosphatidylinositol 3-kinase pathway in $\mathrm{C}_{2} \mathrm{C}_{12}$ murine skeletal muscle cells. J Pineal Res. 2006; 41(1): 67-72.

30. Paradies G, Paradies V, Ruggiero FM, Petrosillo G. Mitochondrial bioenergetics decay in aging: beneficial effect of melatonin. Cell Mol Life Sci. 2017; 74(21): 3897-3911.

31. Hardeland R. Melatonin and the electron transport chain. Cell Mol Life Sci. 2017; 74(21): 3883-3896.

32. Nishida S. Metabolic effects of melatonin on oxidative stress and diabetes mellitus. Endocrine. 2005; 27(2): 131-136.

Received 07.12.2017 